\title{
EARLY PITTSBURGH LAWYERS AND THE FRONTIERS OF ARGUMENT AND DISSENT
}

\author{
Ron Schuler*
}

\begin{abstract}
Pittsburgh, during the period from 1788 through the 1840s, was a city on the frontier of the American Republic. Amid the privations and risks of living in the frontier, the political discourse of the early lawyers of the bar Pittsburgh often concerned itself with questions of self-determination and dissent from the establishment. The methods of argument and dissent by Pittsburgh's early lawyers also reflected the harshness of life on the frontier, as seen in such episodes as the Whiskey Rebellion, the impeachment of Judge Alexander Addison, and the duel between Tarleton Bates and Ephraim Pentland. Henry Baldwin, a Pittsburgh lawyer who had participated in his own duel as well as being a key player in the BatesPentland affair, was appointed to the United States Supreme Court in 1830, and as an associate justice he played a key role in creating the institution of the dissenting opinion on the Court - a fact which may be seen within this context as a frontier influence on American jurisprudence. The end of the early bar and its concerns with dissent coincides with the Civil War, in which 115 Allegheny County lawyers - many of them middle-aged with lucrative practices in full bloom-risked life and limb to preserve order within the Republic.
\end{abstract}

\footnotetext{
* Managing Member of the Pittsburgh office of Spilman, Thomas \& Battle, PLLC. Portions of this article are excerpted from an unpublished work-in-progress, commissioned by the Allegheny County Bar Association, tentatively entitled The Steel Bar: Reinventions of the Legal Profession in an American City of Industry and Commerce, 1788-Present. The author is indebted to Thomas M. Thompson and Bernard Hibbitts for their comments on the unpublished manuscript, and to Samuel I. Yamron for his assistance in finalizing this article for publication.
} 
U N I V E R I T Y OF P I T T S B U R G H L A W R E V I E W

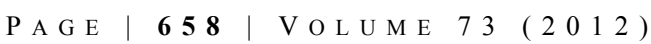

On a November day in 1794, Pittsburgh's first lawyer stood before the Secretary of the Treasury of the United States, Alexander Hamilton, at the center of a hastily convened federal inquest, being suspected of attempting to overthrow the government and fully expecting that he would soon be summarily arrested, convicted and executed.

"I was received," said the lawyer, Hugh Henry Brackenridge,

by Mr. Hamilton with that countenance which a man will have when he sees a person with regard to whom his humanity and his sense of justice struggle ... $[\mathrm{H}] \mathrm{e}$ would have him saved, but is afraid he must be hanged; was willing to treat me with civility, but was embarrassed with a sense that in a short time I must probably stand in the predicament of a culprit, and be put in irons. ${ }^{1}$

Brackenridge's life was ultimately spared, however. "Had we listened to some people," Secretary Hamilton later concluded, "I do not know what we might have done."

The occasion for this inquiry was the aftermath of a little known episode of American history known as the Whiskey Rebellion. If we think of the Whiskey Rebellion at all today, we tend to think of it as an uprising of drunken farmers on the Western frontier of Pennsylvania, putting their hooliganism on full display by firing a few gunshots and tarring-and-feathering a few revenue agents before President George Washington personally led 13,000 federal troops westward to quell the riots. The shorthand version of the event obscures its significance. The Whiskey Rebellion of 1794 was actually the first large-scale resistance to a law enacted by Congress under the newly-ratified United States Constitution. It was, in fact, the first serious test of constitutional power and authority, and its key protagonists were not merely a gang of drunken farmers; rather, among them were some relatively sober lawyers, pushing the limits of democratic discourse, and by doing so, helping to define democratic discourse in the new Republic.

The birth of our nation is often stereotypically represented to us in broad strokes, beginning with a Boston Massacre, a Boston Tea Party and battles at Lexington and Concord-all violent events; then, during and in the immediate

${ }^{1}$ H.M. Brackenridge, History of the Western Insurrection in WeStern PenNSylvania 305 (1859) [hereinafter BRACKENRIDGE History]; see also H.H. BRACKENRIDGE, INCIDENTS OF THE INSURRECTION IN THE WeSteRn PARTS OF PENNSYlVANIA IN THE YeAR 1794 BY Hugh H. BRACKENRIDGE 75 (1795).

${ }^{2}$ Thomas P. Slaughter, The Whiskey ReBellion 219 (1986). 
aftermath of a war with the British prosecuted by General George Washington, a series of philosophical debates among American men (many of them lawyers) wearing powdered wigs, culminating in a series of written resolutions of one kind or another - a Declaration of Independence, some Articles of Confederation, and finally a Constitution. In broad strokes, the American consciousness is shown to leap from violence and brutality to an instant Age of Enlightenment, in which political issues and other disputes suddenly became settled through rational discussions and an orderly democratic process.

The experience of Pittsburgh lawyers in the early American Republic provides an object lesson in how our history - and, in particular, our local historyis a little more nuanced than the broad strokes. In the questions and issues taken up by Pittsburgh lawyers during the period from the 1790s to the Civil War, one can see a strong undercurrent of the need for self-determination in the frontier that was at odds with the democratic processes suggested by the Constitution, a theme that would later manifest itself as the Republic matured in the running debate between those who supported a strong central government and those who favored greater autonomy at the state level. For Pittsburghers at the end of the 18th century, however, violence and brutality were still palpable possibilities in daily life on the frontier. Thus, choosing a life in the West was a calculated risk-even for Pittsburgh's lawyers, a profession not generally known for its risk-taking - and the need for autonomy seems to have grown from the need to assume responsibility and control with respect to the risks of the frontier, especially during an era in which the central government was proving itself inadequate to the task of reducing such risks. Perhaps it should be no surprise that the formal aspects of political discourse of Pittsburgh lawyers during this period also displayed an element of risk-taking that would be uncharacteristic of the lawyers of Philadelphia and Boston, revealing behaviors ranging from aggressive declarations of dissent, to blistering personal attacks, to whippings, duels, and finally, to outright rebellion.

Philadelphia and Boston may have been transformed into civil societies by their proximity to European import trade routes and by a hundred years' head start on the business of building and educating. Pittsburgh, in the 1780s and 1790s, was an outpost on the frontier of the United States, in which attacks by nearby Native Americans were still fresh in the memory of the settlers - for example, the capture of Thomas and Jane Dick near the mouth of Deer Creek, north of Pittsburgh, in March 1791, and the massacre of the Russ family along the Allegheny River, four days later. ${ }^{3}$ To make matters worse for Native Americans, President Washington's

\footnotetext{
${ }^{3}$ History of Butler County, Pennsylvania, With Illustrations and Biographical Sketches OF SOME OF Its PRominent Men AND PiONEers 16 (1883); SLAUGHTER, supra note 2, at 61.
} 
U N I V E R S I T Y OF P I T T S B U R G H L A W R E V I E W

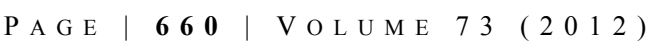

new federal government saw expansion westward as one cure for its financial problems after an expensive war with the British. Under the Northwest Ordinance of 1787 , the Northwest Territory was opened for settlement. While refusing to engage the Native Americans in diplomatic dialogues or in armed conflict, the government began to sell claims on land north and west of the Ohio River, leading in some cases to increased tensions between white settlers and Native American tribes. ${ }^{4}$

Out of necessity, the best of Pittsburgh's earliest lawyers were nimble and opportunistic, both physically and mentally. Fresh from one test of his skill, a Pittsburgh lawyer might jump on his horse and ride across the rolling hills like an armored knight, speeding toward another field of battle; and after a breakneck journey over bad roads - as Pittsburgh lawyer James Mountain famously would in the course of defending one James Bell on a charge of murder in 1809-he might jump off his horse and grab the reins of a case just at the close of evidence, hastily learning the leading points and launching headlong into his closing address to the jury, electrifying them, and gaining a quick acquittal for his client. ${ }^{5}$ Lawyering in Pittsburgh during the early years was, in part, an outdoor activity that required physical stamina and quick-wittedness.

The successful Pittsburgh lawyer during this period would be a master of the land, Pittsburgh's most abundant resource at the time; he would, quite literally, know the terrain, and often he would become skilled in land speculation. Collecting debts locally for his Eastern clients or drafting the documents by which they would deploy their capital, he would develop a sharp insight into human character, and a nose for the next lucrative opportunity. Although, like his Eastern counterparts, he might have a healthy respect for erudition, he was unlikely to have an extensive library; rather, he had to rely on his shrewdness, and his practical, street-level common sense, both in providing advice and in persuading judges and juries.

While the Western Pennsylvania frontier may have encouraged lawyers to be shrewd, aggressive athletes, nonetheless, lawyers, by profession, are creatures of an archetypal Age of Enlightenment construct: the notion that men of action and property can procure the services of men of words to represent them in their disputes, and to resolve them (or to win them, to be more precise) through the use of rules and rational discourse, and notably, without the necessity of bloodshed.

\footnotetext{
${ }^{4}$ See Wiley SwORd, PRESIDENT Washington's INDIAN WAR 45-51 (1985).

${ }^{5}$ Daniel Agnew, Address to the Allegheny County Bar Association, 13 PA. Mag. Hist. \& Biography 32 (1889).
} 
Few understood this "order creating, order preserving" function of the legal profession better than the first Pittsburgh lawyer, Hugh Henry Brackenridge.

Brackenridge was born in Scotland in 1748, and he came to America with his parents. By the age of 16, he was a schoolmaster in rural Maryland. A few years later, he attended Princeton with fellow patriots-in-training James Madison and Philip Freneau, and had demonstrated his commitment to a free and independent United States well before the Continental Congress would vote on the issue, in a prophetic commencement poem, The Rising Glory of America (co-written with Freneau) and in politically-tinged sermons he would write while serving as a chaplain in the Revolution. ${ }^{6}$ After the Revolution, he studied law in Philadelphia, where he had initially intended to practice. ${ }^{7}$ However, awed by the presence of such imposing legal minds as Pennsylvania's colonial chief justice Benjamin Chew, and leading lights of the Continental Congress such as John Dickinson and James Wilson, he quickly came to realize that he "had no chance of being anything in that city, there were such great men before me" Pennsylvania - "to advance the country and thereby myself" - and began practicing law in Pittsburgh, as a member of the Westmoreland County bar, at the age of thirty-three. ${ }^{9}$

Late in his career, while serving as a justice on the Pennsylvania Supreme Court, Brackenridge would write, "The profession of the law under a Republican Government, not only leads to emolument, but qualifies for political eminence." In his actions and written words he embodied the notion that lawyers - as educated, rational men, and agents of civilization - were specially equipped, if not obliged, to play a key role in defining the new republic and its political institutions. They would help to create order out of the passions that transformed the colonies into independent states, especially in the unruly Western frontier. As Daniel Marder writes:

\footnotetext{
${ }^{6}$ See Slaughter, supra note 2, at 254; Daniel Marder, A Hugh Henry Brackenridge Reader, $1770-1815$, at 7 (1970).

${ }^{7} I d$.

${ }^{8}$ MARDER, supra note 6, at 7.

${ }^{9}$ Id. at 6 .

${ }^{10}$ Hugh Henry BrackenRidge, Law Miscellanies: Containing An InTROduction to the Study OF THE LAW viii (1814).
} 
U N I V E R I T Y OF P I T T S B U R G H L A W R E V I E W

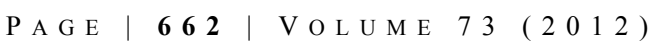

The problem ... how to be both free and orderly ... consumed the life of Hugh Henry Brackenridge at the beginning of the democratic experiment. He was totally committed and utterly involved .... He was committed completely to the requirement of an educated and sensitized population, and he was involved, therefore, in overcoming ignorance and licentiousness. ${ }^{11}$

Brackenridge had arrived in the village of Pittsburgh at the height of a secessionist boomlet. Here on the Western frontier, some of the locals had been agitating for the creation of a new state or perhaps even a new nation in the region, largely because of the apparent indifference of the government in the East to the problems of the Westerner-in particular, the ongoing warfare with Native Americans in the area; the increase in white population at the same time that opportunities for land ownership seemed to be on the decline, placed within the hands of wealthy absentee landlords in the East; the government's refusal to secure navigation rights to the Mississippi River from the Spanish, which would have aided the ability of Western Pennsylvania to engage in trade; and a general lack of cash and commercial prospects. ${ }^{12}$

In 1786, Brackenridge helped to launch a newspaper, the Pittsburgh Gazette, and shortly thereafter was elected to the Pennsylvania Assembly, where he strongly supported the ratification of the United States Constitution. Brackenridge's public support for the Constitution, however, probably cost him his chance to be reelected to the Assembly in 1787 after one term, despite the fact that as a one-term assemblyman he had led the fight to establish Allegheny County and secured state endowments for the academy that would eventually become known as the University of Pittsburgh. Popular sentiment in Western Pennsylvania at that time favored the rights of independent states over the creation of a centralized federal government, but Brackenridge saw the Constitution as a much-needed stabilizing force that would help mold the confederation of American states into a true nation. ${ }^{13}$

Meanwhile, the new federal government was beset by a number of challenges - principal among them, the fact that the new nation was beginning its life under the weight of millions of dollars in debt, due to costs incurred in waging the Revolutionary War. In response to the financial crisis, Secretary Hamilton

\footnotetext{
${ }^{11}$ MARDER, supra note 6, at 5-6.

${ }^{12}$ See SlaUghter, supra note 2, at 36-37.

${ }^{13}$ See SLAUGHTER, supra note 2, at 72; MARDER, supra note 6, at 37.
} 
pushed for a plan that he hoped would reduce the remaining debts from the Revolution, as well as create a steady stream of revenue that would begin the process of turning the United States government into a vehicle for raising capital through the sale of bonds. ${ }^{14}$ In the summer of 1790, Hamilton called for an excise tax on the production of whiskey. As enacted in March 1791, the tax tended to weigh more heavily on country stills west of the Alleghenies than it did the larger commercial stills of the metropolitan East, with the result that smaller distillers often ended up having to pay more than twice per gallon what larger producers paid. This inequity was compounded by the fact that whiskey was used as currency in places like Pittsburgh, where cash was scarce; every fifth Pittsburgher had a whiskey still, just to help make ends meet. ${ }^{15}$ Finally, anyone who wished to protest the levy of the tax on their stills in Western Pennsylvania would be forced to leave their farming and other business unattended for a significant period of time to travel to Philadelphia and wait out a notoriously vague and imprecise court calendar. To be sitting outside the courthouse in Philadelphia while it was harvest time in Allegheny County could be financially devastating for an Allegheny farmer. ${ }^{16}$

Back in Pittsburgh practicing law and editing the Gazette when the whiskey tax was enacted, Brackenridge propelled himself to the forefront of a petition movement to repeal the whiskey tax, portraying the tax as a threat to liberty analogous to the British stamp tax imposed on American colonists before the Revolution. ${ }^{17}$

In September 1791, several unidentified hoodlums ambushed a newlyappointed revenue collector named Robert Johnson near Pigeon Creek, south of the Monongahela. They yanked Johnson from his horse, stripped him naked, and tarred and feathered him. Although Brackenridge was against the excise tax, he was also against the violent redress of grievances; he respected the Constitution and urged his fellow Westerners to work through Congress to have the law changed. "A revolution did not suit me," Brackenridge would recall, "nor any man else who had anything to lose." ${ }^{, 18}$ Nevertheless, Secretary Hamilton and others within the federal

\footnotetext{
${ }^{14}$ See SLAUGHTER, supra note 2, at 95-105.

${ }^{15}$ See id.

${ }^{16}$ See Slaughter, supra note 2, at 95-105. William Hogeland, The Whiskey Rebellion 68-69 (A Lisa Drew Book/Scribner 2006).

${ }^{17}$ See SLAUghtER, supra note 2, at 95-105; MARDER, supra note 7, at 49-50.

${ }^{18}$ See id.
} 
government saw Brackenridge, through his position of influence, as a dangerous radical, and they immediately linked Brackenridge with the violence. ${ }^{19}$

Another one of the first members of the Allegheny County bar, David Bradford, would be much more strident in his opposition to the tax than Brackenridge. Although he served as deputy attorney general (district attorney) for Washington County and had familial connections with powerful men (his sisters had married John McDowell and James Allison, two very prominent Western Pennsylvania lawyers), Bradford did not enjoy significant political influence before the enactment of the whiskey tax. Like Brackenridge, Bradford served briefly in the Assembly, but was seen as an undistinguished legislator. Albert Gallatin, who also served with him there, called Bradford "an empty drum, as ignorant, [indolent] \& insignificant as he is haughty \& pompous." With the unrest building in Western Pennsylvania, Bradford showed his allegiances by refusing to prosecute anyone for the attacks on revenue agents. ${ }^{20}$

In July 1794, matters came to a head with an attack by anti-tax forces on the Bower Hill home of the federal inspector of revenue, General John Neville, after Neville tried to serve a summons on a local still owner. In the ensuing 25-minute musket battle, one rebel was killed and several others were wounded. Thirsty for revenge, the rebels regrouped, returned to Neville's house and rejoined the battle, with the result that the leader of the rebels, John MacFarlane, was killed, and Neville's home was burned to the ground.

At a gathering of rebels at Mingo Creek after the incident at Bower Hill, David Bradford delivered what one witness called a "violent and inflammatory oration" in support of amassing an army to oppose the federal government, talking of setting up guillotines and predicting that an army of Western Pennsylvania rebels would defeat any federal army that might come over the Alleghenies. ${ }^{21}$ By contrast, Brackenridge tried to calm the crowd, telling jokes and reminding people that the local revenue agent at Pittsburgh had already closed his office. He concluded by observing that what had been done at Neville's farm was "morally right, but legally wrong" - treasonous, in fact — and that President Washington now

\footnotetext{
${ }^{19}$ See SlaUghter, supra note 2, at 218-19; HogelAND, supra note 16, at 233-35.

${ }^{20}$ James P. McClure, 'Let Us Be Independent': David Bradford and the Whiskey Insurrection, PitTSBURGH Hist., Summer 1991, at 75.

${ }^{21}$ BRACKENRIDGE History, supra note 1, at 72-74.
} 
had unequivocal grounds to bring a federal militia to Western Pennsylvania. Finding his audience unreceptive, Brackenridge departed quickly. ${ }^{22}$

Bradford's activities, his version of democratic argument, now began to look a lot like a war of independence. Bradford allegedly directed the ambush of a postal rider carrying letters from Washington, Pennsylvania to Pittsburgh; and after examining the letters, Bradford drew up a circular calling for the assembly of a militia at Braddock's Field. Around 7,000 men showed up at Braddock's Field on August 1, and Bradford wasted no time in calling for the assembled militia to march into Pittsburgh — both as a show of force, and to take hold of the federal garrison there, with its stores of ammunition and other supplies. For many of the propertyless country boys who joined the rebel army, Pittsburgh ironically symbolized the greed and power of the big cities of the East, and they were motivated by more than military strategy to take hold of Pittsburgh and burn it to the ground. ${ }^{23}$

As Bradford brought his army to Pittsburgh, though, Brackenridge did his best behind the scenes to file down the edges of the conflict, urging Pittsburghers to show the rebels their hospitality by giving them food and casks of whiskey. Bradford, who remained defiant but did not want the blood of innocent Pittsburghers on his hands, also gave Pittsburgh an opportunity to escape destruction, demanding the expulsion of certain persons friendly to the federal cause in exchange for sparing the city. The rousing welcome disarmed the rebels as they entered Pittsburgh on August 2, and they soon dispersed peacefully, if somewhat aimlessly. A combination of whiskey and lawyers, applied judiciously, outmaneuvered the guns on this occasion. ${ }^{24}$

The events of the summer were close to spinning out of control, and President Washington saw no choice but to show Western Pennsylvania the might and authority of the federal government. Marking the only time in American history that a sitting president ever personally led an army into potential battle, President Washington rode his white steed as far west as Bedford with 13,000 troops under his command. On October 24, 1794, Washington's army, now led by General Henry "Lighthorse Harry" Lee, arrived in Washington County to subdue what was left of the rebellion. The Whiskey Rebellion had, in effect, been broken, and President Washington's aim of showing federal might—and the force of federal

\footnotetext{
${ }^{22} I d$.

${ }^{23}$ See SlAUghter, supra note 2, at 185-88; Hogeland, supra note 16, at 156-57.

${ }^{24}$ See SLAUGHTER, supra note 2, at 185-88.
} 
U N I V E R S I T Y OF P I T T S B U R G H L A W R E V I E W

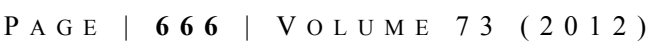

law-had been achieved. In the months and years that followed, however, Western Pennsylvanians would enjoy the benefit of increased attention from the federal government: the Native Americans would be pushed further west, the Mississippi would be opened for traffic by treaty, and a new federal court would be located in Pittsburgh.

Shortly before the arrival of General Lee and his troops, David Bradford, who was by now openly advocating independence for Western Pennsylvania, fled the region with a price on his head, taking a coal barge from Pittsburgh down the Ohio River. He made his way down the Mississippi, eventually landing at Bayou Sara, above Baton Rouge in Spanish Louisiana.

In May 1795, a federal grand jury indicted Bradford on a charge of high treason, and he was specifically excluded from a number of general pardons that were granted in the aftermath of the Insurrection. ${ }^{25}$ Still living at Bayou Sara, Bradford applied to Washington's successor, President John Adams, for a specific pardon in the fall of 1798; and as tempers cooled, Bradford finally received his pardon in March 1799. ${ }^{26}$ Adams' successor, Thomas Jefferson, successfully called for the repeal of the whiskey tax in 1801, and in the winter of 1803-04, Jefferson thought of David Bradford once again. Conferring with members of the Senate, Jefferson expressed the view that the Florida Territory rightfully belonged to the United States; and in aid of taking possession of it, Jefferson suggested that perhaps David Bradford could be convinced to lead an insurrection of American squatters against the Spanish. ${ }^{27}$ The possibility of bringing Bradford out of retirement was halted when Jefferson started negotiations for the purchase of Florida in 1805, but Adams' pardon and Jefferson's aborted plan do tend to show that at least some members of the American establishment saw Bradford's actions in Western Pennsylvania as forgivable under the circumstances. ${ }^{28}$ The American Revolution, an exercise in a frontier people securing greater political autonomy from the central government, was only a few years old at the time. It is possible that the federal government could forgive one of its citizens for his agitation for greater autonomy on the frontier. Significantly, there does not seem to have been any effort to have David Bradford disbarred.

${ }^{25}$ McClure, supra note 20, at 77.

${ }^{26} I d$.

${ }^{27}$ M. Avis Pitcher, John Smith, First Senator from Ohio and His Connections with Aaron Burr, 45 OHIO ST. ARCHEOLOGICAL \& HiST. Q. 68, 76 (1936).

${ }^{28}$ McClure, supra note 20, at 77. 
Meanwhile, Hugh Brackenridge, as one of the early opponents of the whiskey tax, was targeted by members of the federal militia for immediate execution. Brackenridge reluctantly turned himself in, fearing he would be made a scapegoat for the whole affair. Despite Brackenridge's hopes for orderly, enlightened political engagement to resolve a legitimate dispute, he found that the first impulse of his constitutional government, in response to his reasoned dissent from federal policy, was to execute him for treason. Once Secretary Hamilton conducted his interrogations, however, he concluded that Brackenridge was not a traitor, and Brackenridge was never charged. After a near-death experience, Brackenridge would find that rational argument could be tolerated under the new constitutional system. Although he survived his adventure, Brackenridge risked his livelihood in Pittsburgh, and lost it; after the Whiskey Rebellion, he found little support from either the federalists or the anti-constitutionalists. He moved to Carlisle, Pennsylvania, and was later appointed to the Pennsylvania Supreme Court. ${ }^{29}$

This nuanced Pittsburgh version of the Age of Enlightenment, while helping to define the limits, language and decorum of political dissent in the United States, also showed a surprising tolerance for physical engagement-surprising to us today, although consistent with the prevailing circumstances of the Pittsburgh frontier. It reveals the tension in the Pittsburgh bar during the end of the 18th century and the first half of the 19th century between the rational dialogue that Brackenridge craved, and the tradition of aggressive self-help that seemed to define life on the frontier.

The Whiskey Rebellion itself, meanwhile, was a watershed event in Pittsburgh politics, finding its echoes in subsequent debates between federalists and anti-constitutionalists for years to come, as well as in the intensity of existing rancor within the Pittsburgh bar.

One direct effect of the Whiskey Rebellion on the Pittsburgh bar was the impeachment of the first Allegheny County District Court judge, Alexander Addison. Addison was a devoted Federalist who, during the Rebellion, had eluded capture by the rebels while riding east to provide evidence of illegal activity to the federal government. ${ }^{30}$ Before the election of a Democratic-Republican, Thomas McKean, in 1799, Judge Addison had a penchant for delivering long addresses during jury instructions on the dangers of Democratic-Republicanism. During one

\footnotetext{
${ }^{29}$ See Slaughter, supra note 2, at 254; Leland Baldwin, Whiskey Rebels: The StORy of A FRONTIER UPRISING 236-42 (University of Pittsburgh Press 1967).

${ }^{30}$ Wm. G. Johnston, Centennial Volume of the First Presbyterian Church of Pittsburgh, PA., 1784-1884, at 142 (1884).
} 
U N I V E R I T Y OF P I T T S B U R G H L A W R E V I E W

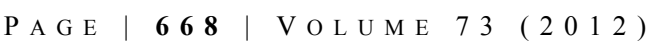

famous jury charge in 1800, Judge Addison delivered an address on the "Rise and Progress of Revolution," observing that revolution occurs in phases, beginning with the destruction of the Christian religion, followed by the destruction of political and social institutions, and giving liberal examples from the activities of the Jacobins in France and the Illuminati in Germany.

Judge Addison gave another variation of his speech on the French Jacobins, along with the observation that the election of Thomas McKean as Governor was evidence of the growing influence of radicalism in Pennsylvania. This time, however, Judge John B.C. Lucas, a French-born Democratic-Republican, began to address the jury with a prepared speech defending the Democratic-Republicans. Judge Addison and his fellow Federalist, Associate Judge John McDowell, constituting a majority, cut Judge Lucas off, threatening to have Judge Lucas removed from the courtroom if he proceeded, and ordering the jury to disregard Judge Lucas' entire speech. ${ }^{31}$

In his anger over being embarrassed by Judge Addison in open court, Judge Lucas appealed to the Pennsylvania Supreme Court by filing an indictment against Judge Addison for a misdemeanor in office. The Court dismissed the indictment, stating that Judge Addison had shown no malice in stopping Judge Lucas from speaking; so Judge Lucas brought his cause to the Pennsylvania House in January 1802, with petitions signed by almost 700 inhabitants of Allegheny and surrounding counties asking for the impeachment of Judge Addison. In compliance with the petitions, the House made out articles of impeachment and presented them to the State Senate. ${ }^{32}$

Alexander J. Dallas, who would later serve as President Madison's Secretary of the Treasury, led the prosecution in the Senate; Judge Addison represented himself. The trial began on January 17, 1803. Dallas took testimony from Judge Lucas and a collection of Democratic-Republicans, including the county court prothonotary, Tarleton Bates. Addison's only witness was his other colleague on the bench, Judge McDowell. Addison tried to present affidavits from witnesses who were unable to make the trip from Pittsburgh to the Senate sitting in Lancaster, but was rebuffed. The parties all agreed that Judge Addison had restrained Judge Lucas from speaking, and had threatened to find the means to stop him if he persisted. What remained in conflict from the testimony was whether or not Judge

\footnotetext{
${ }^{31}$ See J.W.F. White, The Judiciary of Allegheny CounTy 15 (1883).

${ }^{32}$ Id. at $15-16$.
} 
Addison did so angrily, which would be evidence of malice. It was difficult to tell; Judge Addison was known to speak in a loud voice even in ordinary conversation.

In his closing address, Judge Addison admitted the unpopularity of his Federalist bias, but did not veer from his belief that his exercise of judgment on the bench was for the good of the republic:

No man can be less qualified than I for avoiding unpopularity. I have no taste for intrigue, no disposition for flattering the follies or passions of men; no propensity to false arts; no desire for revenge, to spur my invention of means to oppose my adversaries. ... In a republican government, it ought to be deemed the honour of an officer to discharge his duty with fidelity, regardless of favour or resentment; to be guided by the laws and interest of the country, not by popular prejudices, passions, or opinions; and to pursue the public good, whether public favour followed it or not. On such principles and conduct have I rested my official reputation; and not on trimming my sails to the gale of popularity, or shifting the course with the tide of the times. ${ }^{33}$

The impeachment trial was a political trial, however, brought by DemocraticRepublicans against a defiant Federalist, and Judge Addison went down in defeat by a vote of 20 to $4 .{ }^{34}$ On January 27,1803 , the Senate pronounced its sentence, removing Judge Addison as president judge of the Fifth District Court, and declaring him forever disqualified from holding a judicial office in the state. Addison had suffered, figuratively speaking, a political execution.

Addison's impeachment occurred at the beginning of a brief American "reign of terror" in which a number of judges became targets of politically-motivated impeachment proceedings. In 1804, the Pennsylvania House prepared articles of impeachment against all of the Federalist justices on the Pennsylvania Supreme Court-Chief Justice Edward Shippen and Associate Justices Jasper Yeates and Thomas Smith - in response to a petition from one Thomas Passmore, who argued that their conviction of him for contempt of court was a violation of the Bill of Rights. The remaining Associate Justice, the former Pittsburgher Hugh Henry Brackenridge, may have been a Democratic-Republican sympathizer, but he was outraged by the use of impeachment for political means, and demanded to be

\footnotetext{
${ }^{33}$ Thomas Lloyd, The Trial of AleXander Addison, EsQ. ON AN IMPEAChMENT, By THe House of Representatives, Before the Senate of the Commonwealth of Pennsylvania 137-38 (Lloyd \& Helmbold $2 \mathrm{~d}$ ed. 1803).

${ }^{34}$ See White, supra note 31 , at $15-16$.
} 
U N I V E R S I T Y OF P I T T S B U R G H L A W R E V I E W

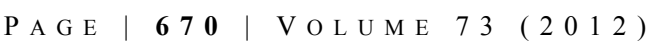

impeached along with his brethren. Shocked at Brackenridge's lack of party loyalty, the House urged Governor McKean to remove Brackenridge, but he refused. Shippen, Yeates and Smith were eventually acquitted. ${ }^{35}$ Later that year, Associate Justice Samuel Chase of the United States Supreme Court, an appointee of President Washington, was served with eight articles of impeachment by the Democratic-Republican controlled House of Representatives, but the Senate voted to acquit Chase of all charges on March 1, 1805.

One of the witnesses against Judge Addison, the county prothonotary Tarleton Bates, was involved in another violent political episode affecting the Pittsburgh bar, known as the "Last Duel in Pittsburgh." Although trained for the law, Bates secured a position as a clerk in the U.S. Army Commissary Department under Major Isaac Craig, son-in-law to General John Neville, the government inspector who lost his home during the Whiskey Rebellion, and eventually ascended to the position of County Court prothonotary. As Bates took his position with the courts, the electoral tide was just beginning to turn in favor of the DemocraticRepublicans; and as a passionate Democratic-Republican, still in his 20s, Bates became one of the most public supporters of the Party, along with a pair of young Pittsburgh lawyers, Henry Baldwin and Walter Forward. The three young menBates, Baldwin and Forward-were known as the "Great Triumvirate" around town: young, robust and handsome, they were all fervent partisans with terrific powers of expression, dashing men-about-town, attending all the best picnics, horse races and parties. They were also the leaders of what became known as the "Clapboard Row Junto," meeting most evenings at the "Sign of General Butler," a tavern in the Diamond. ${ }^{36}$

Meanwhile, in the wake of the near-demise of the Federalists, the Democratic-Republicans began to experience their own schism: a moderate "Constitutionalist" wing that supported Governor McKean, was beginning to be opposed by a group of more radical "states' rights" Democratic-Republicans, known as the "True Republicans." The members of the Great Triumvirate were supporters of the moderate wing, whose main journal was the Tree of Liberty. Meanwhile, an acerbic young Pittsburgh journalist named Ephraim Pentland edited a "True Republican" journal called the Commonwealth. After Governor McKean's re-election, on Christmas Day, 1805, Pentland ran a column in The Commonwealth

\footnotetext{
${ }^{35}$ Hugh Henry Brackenridge as Judge of the Supreme Court of Pennsylvania 1799-1816, 10 W. PA. Hist. MaG., Oct. 1927, at 210; Solon J. Buck \& Elizabeth Hawthorn Buck, The Planting of CiVilization in Western PenNSYlvania 478 (1939).

${ }^{36}$ T.L. Rodgers, The Last Duel in Pennsylvania, 12 W. PA. HIST. MAG., Jan. 1929, at 54-56.
} 
attacking Bates and Baldwin as "two of the most abandoned political miscreants that ever disgraced the state," and accusing them of being fickle enough to back whomever was in power, without principle.

On the night of January 2, 1806, Bates decided to take his argument directly to Pentland. Seeing him outside the office of the Commonwealth, Bates stormed across the Diamond and began to cowhide Pentland with his whip. Suffering two or three lashes from Bates, Pentland turned and ran to the authorities. Pentland's account was that he was ambushed in the dark, and that Bates had two of his friends along, Henry Baldwin and another Pittsburgh lawyer, Steele Semple, in case he needed help; both of them "limbs of the law," Pentland wrote, adding ironically that, as lawyers, they were also undoubtedly "students of morality." Bates, however, wrote on January 4 in the Tree of Liberty that the moon was full that evening, and so there was plenty of light for a good fight, and that he was alone. Moreover, he wrote, Pentland acted like a complete coward. The same issue of the Tree of Liberty also carried a letter from Baldwin and Semple, confirming Bates' account of the event.

Although he originally intended to file assault charges against Bates, Pentland made a tactical decision to challenge Bates to a duel instead. Duels were not altogether uncommon among these "men of words." Not long before, Henry Baldwin had fought a duel against another lawyer, Isaac Meason, Jr., over a grievance that has been described as either political or romantic in naturepossibly both. During the first round of pistol-fire, Baldwin was hit in the chest and began spitting up blood, so witnesses feared he had been shot through; but apparently a Spanish silver dollar in Baldwin's waistcoat pocket deflected Meason's bullet. The parties were scared off by a posse sent by Judge Riddle before they could lob a second volley. ${ }^{37}$ At Meadville in 1800, Pittsburgh lawyer Alexander W. Foster dueled with Major Roger Alden over a love affair; and despite the fact that Major Alden was crippled by Foster's shot, history records that Major Alden won the escapade, having won the heart of the woman in question in the process of being wounded by Foster. ${ }^{38}$

When Pentland challenged Bates, it had been a year and a half since Alexander Hamilton had been shot and killed by Aaron Burr in the most notorious duel of the young republic, but even before that dreadful case, Pennsylvania had

${ }^{37}$ M. Flavia Taylor, The Political and Civic Career of Henry Baldwin, 1799-1830, 24 W. PA. HisT. MAG., Mar. 1941, at 37; Agnew, supra note 5.

${ }^{38}$ Agnew, supra note 5. 
U N I V E R S I T Y OF P I T T S B U R G H L A W R E V I E W

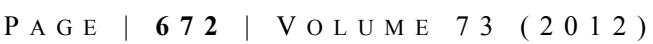

outlawed dueling in 1794, on pain of losing one's citizenship for seven years, as well as a fine and imprisonment. Pentland's challenge posed a dilemma for Bates; although accepting a duel would mean that Bates would lose his public position as prothonotary, not accepting it would be seen in public as taking the coward's way out. $^{39}$

One of Pentland's associates, a dry goods merchant named Thomas Stewart, carried the challenge to Bates personally on January 6, 1802, and as Pentland expected, Bates declined. ${ }^{40}$ That night, Pentland placed printed placards around the town that declared that Bates was a "coward and a poltroon." 41 Bates responded angrily in the next issue of the Tree of Liberty, saying that he was provoked, after receiving so much personal insult in the pages of the Commonwealth, "into correcting the licentiousness of the press with the liberty of the cudgel" - or in Bates's case, the whip. ${ }^{42}$ As to the invitation to duel, however, he said he had no more respect for the man who delivered the challenge (Stewart) than for Pentland himself, and that therefore he might be tempted to lash at Stewart as well. ${ }^{43}$

To Pentland and his friends, Bates' insult of Stewart was an escalation. Another young member of the bar, William Wilkins, showed up at the Tree of Liberty and demanded an apology and a retraction from Bates on behalf of Pentland and Stewart. Bates refused, sending a note back saying that he "did not especially intend an implication of Mr. Stewart, nor specifically mean to excuse him." Egged on by Pentland and Wilkins, Stewart immediately challenged Bates to a duel, and Bates felt he had no choice at that point but to accept. ${ }^{44}$

Wilkins acted as Stewart's second, and Bates had Morgan Neville, a law student who was the grandson of General John Neville. The seconds worked out the details: they were to fight the duel the next day on land near the old Chadwick Farm where Three Mile Run emptied into the Monongahela. On the cold and damp morning of January 8, the parties and their seconds met at Three Mile Run. The seconds prepared the pistols, loading powder and ball in each, and Bates and

\footnotetext{
${ }^{39}$ Rodgers, supra note 36 , at 54-56.

${ }^{40} \mathrm{Id}$.

${ }^{41} I d$.

${ }^{42} I d$.

${ }^{43} I d$.

${ }^{44} I d$.
} 
Stewart took their stands approximately ten paces apart. As Michael Franchioni writes:

Standing back to back, then marching 10 paces, turning and firing, was not typical - aiming these weapons was difficult enough from a stationary position. The short, smooth bore of the pistols, an imprecise measure of powder and an only approximately spherical ball made the weapons wildly inaccurate, even as close as 10 paces. Only about one duel in 14 proved fatal. ${ }^{45}$

The two men stood in the traditional sidestance dueling pose-with one's right leg in front of the left, looking over one's right shoulder and extended arm. Wilkins called out to Bates that an apology could still be accepted, but Bates did not answer him. One of the attending party then gave the commands. "Ready? Fire!"46

Stewart and Bates each fired twice; the first shots missed, but in the second round, Stewart struck Bates in the chest. Bates fell over, and before a physician could be reached, he died from his wound. ${ }^{47}$

The Pittsburgh Gazette observed that "The behaviour of the principals on the ground was perfectly calm and undaunted, and this unfortunate transaction was conducted in conformity to the arrangements, which had been previously made, and to the strictest rules of honour." 48 Pentland, however, still could not resist his worst editorial instincts, persisting in calling the late Tarleton Bates a "coward" and a "liar.",49

The largest funeral crowd in the history of Pittsburgh up to that time gathered at Trinity Episcopal Church for the funeral of Tarleton Bates, who was buried in an unmarked grave there in accordance with his wishes. In view of the public outrage over Bates' death, Thomas Stewart fled to Baltimore; his store in Pittsburgh closed within a month after the incident. William Wilkins, too, was forced to leave Pittsburgh for a time, fleeing to a brother's home in Kentucky.

${ }^{45}$ Michael Franchioni, Op-Ed., The Next Page: When Political Debate Really Was Deadly Serious, PitTSBURGH POST-GAZETTE, Oct. 22, 2006, http://old.post-gazette.com/pg/06295/731679-109.stm.

${ }^{46}$ Rodgers, supra note 36 , at $54-56$.

${ }^{47} I d$.

${ }^{48} I d$.

${ }^{49}$ James D. Van Trump \& James Brian Cannon, An Affair of Honor: Pittsburgh's Last Duel, 57 W. PA. HIST. MAG., July 1974, at 307. 
In 1808, Simon Snyder, the "True Republican," would finally be elected Governor, which assured the installment of Ephraim Pentland as the new county court prothonotary; and Tarleton Bates was immortalized by the naming of Bates Street, which plunges down old Three Mile Run toward the Parkway East and the Monongahela River, near the site of the fatal duel. ${ }^{50}$

In the years that followed, Henry Baldwin, Walter Forward and even William Wilkins would all survive their connection as supporting players in the sordid story surrounding the death of Tarleton Bates. The fact that they would prosper-not only as leading members of the bar of Allegheny County but as actors on the national legal and political stage ${ }^{51}$ — was probably a testament to the unquestioned talent and integrity of these young men, and the growing political and economic importance of Pittsburgh. It was also, undoubtedly, a recognition by the establishment that, on the frontier, democratic discourse was bound, occasionally, to take a violent turn.

Henry Baldwin, in particular, prospered. He was elected as an Independent (Democratic) Republican to Congress in 1816 on the strength of his support for higher tariffs on European goods - a position near-and-dear to the awakening manufacturing interests of greater Pittsburgh following the opening of trade after the War of 1812, but one which put him at odds with his agrarian friends in the old Democratic-Republican Party and his Democratic brethren in the South. As chair of the Committee on Manufactures, his advocacy of higher tariffs was so strident and so effective that among contemporaries he shared the title of "father of the American System" with his House colleague, Henry Clay. ${ }^{52}$

While in Congress, however, Baldwin gained the unfailing gratitude of at least one prominent Southern Democrat, General Andrew Jackson. In 1818,

\footnotetext{
${ }^{50}$ Rodgers, supra note 36, at 54-56.

${ }^{51}$ After the Bates incident, as described here, Henry Baldwin served as a member of Congress and as an Associate Justice of the Supreme Court of the United States. Walter Forward succeeded Baldwin in his congressional seat, serving from 1822 to 1825 . Forward also served as President John Tyler's Secretary of the Treasury from 1841 to 1843 , as Chargé d'Affaires (U.S. ambassador) to Denmark from 1850 to 1851, and as a judge on the Allegheny County District Court from 1851 until his death the following year. William Wilkins served as a U.S. District Court judge for the Western District of Pennsylvania from 1824 to 1831, as U.S. Senator from Pennsylvania from 1831 to 34, as U.S. minister to Russia from 1834 to 1835, as a member of Congress from 1843 to 1844, and as President Tyler's Secretary of War from 1844 to 1845. See The Twentieth Century Bench and Bar of Pennsylvania 810-14, vol. 2 (Chicago, H.C. Cooper, Jr., Bro. \& Co. 1903).

52 James A. Kehl, Ill Feeling in the ERA of Good Feeling: Western Pennsylvania Political Battles 1815-1825, at 74-75 (1956); Murray N. Rothbard, The PaniC OF 1819: Reactions and POLICIES 216 (2007).
} 
General Jackson invaded Spanish-controlled Florida, allegedly without obtaining permission from President Monroe, and he nearly sparked an international incident when he summarily ordered the execution of two British subjects whom he had accused of inciting rebellion among the Seminoles. ${ }^{53}$ While many of Baldwin's colleagues in the House were ready to censure Jackson for his actions, Baldwin rose in defense of the General, and - taking a point of view that was no doubt inspired by the prevailing legal climate in his native Pittsburgh — said that Jackson understood American laws and principles better in the wilderness of Florida, without a library, than many men who had actual books at their disposal. ${ }^{54}$ Baldwin was later an enthusiastic supporter of General Jackson's bids for the presidency, first in 1824, and subsequently in Jackson's successful 1828 campaign.

In November 1829, Justice Bushrod Washington, the nephew of George Washington, died while on circuit duty in Philadelphia, and President Jackson rewarded Baldwin, the former Pittsburgh duelist, by nominating him for Washington's seat on the United States Supreme Court. Baldwin was easily confirmed over the protests of the Vice President, 40-2, and Baldwin took his seat on the Supreme Court. ${ }^{55}$

The Court at that time was led by Chief Justice John Marshall, an old-line Federalist whose opinions on the Court reflected an overall expansion of federal powers. Long before Baldwin arrived on the Court, Marshall had abolished the prior habit of permitting seriatim opinions (i.e., a series of opinions by more than one justice on the Court), resulting in the impression that the Marshall Court always spoke with a unified voice. ${ }^{56}$ Thus, there were few published dissents on the Marshall Court until Baldwin joined it; but in his first three terms on the Court, Baldwin dissented twelve times. ${ }^{57}$ Baldwin protested against federal restraints on interstate commerce, and generally took the position of preserving states' rights, especially when federal power found itself at odds with state power-although Baldwin was never inflexible about the supremacy of state or federal power.

\footnotetext{
${ }^{53} I d$.

${ }^{54} 6$ Author of the Thirty YeArs' View, Abridgement of the Debates of Congress, From 1789 TO 1856, at 321 (1858).

55 Timothy S. Huebner, The TAney Court: Justices, Rulings And Legacy (2003); Herbert A. Johnson, THE ChiEF JustiCeship OF John MARShall 1801-1835 (1997).

${ }^{56}$ Johnston, supra note 30, at 96-100; G. Edward White, The Internal Powers of the Chief Justice: The Nineteenth-Century Legacy, 154 U. PENN. L. REV. 1463, 1470 (2006).

${ }^{57}$ HUEBNER, supra note 55; JOHNSTON, supra note 30.
} 
U N I V E R S I T Y OF P I T T S B U R G H L A W R E V I E W

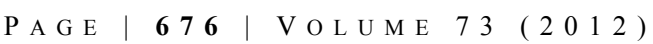

Baldwin's perseverance on the matter of dissenting opinions was partially responsible for inspiring today's common practice of publishing them alongside the majority opinion in the official reports. When Richard Peters, Jr., the reporter of the decisions of the Supreme Court, failed to publish some of Baldwin's dissenting opinions as part of the official record of the Supreme Court, Baldwin argued violently with Peters. Baldwin and Peters reached a kind of stilted détente on the matter, reflected, for example, in the extant footnotes to Ex parte Bradstreet, at the end of the opinion, Peters includes a note to Baldwin ("Sir - I take the liberty to inclose a copy of the clerk's entry of the case 'Ex parte Martha Bradstreet,' and to ask if you dissented from the order of the court in the case. I shall be obliged by the return of the paper."), followed by the text of Baldwin's written dissent in the case. $^{58}$

Not content to wait for Peters to agree with the idea of publishing dissenting opinions as a matter of course, however, Baldwin published some of his opinions in his own pamphlet, A General View of the Origin and Nature of the Constitution and Government of the United States (1837) in which he explained his "peculiar view of the constitution." It has been fashionable for many years to say that Baldwin was an erratic jurist - that not only was he subject to paranoia and mood swings in his later years (the kind of behavior that led Justice Joseph Story to describe Baldwin as "uncomfortable, conceited, willful and wrong-headed," not to mention "partially deranged"60), but that his jurisprudence was inconsistent. In the final analysis, despite the obtuseness of his pamphlet, what is clear from a review of his opinions is that Baldwin believed that both an extreme view of state sovereignty and a too-enthusiastic expansion of federal power were both bad for jurisprudence; and that by being sensitive to political concerns, the Court could play the role of mediator in disputes between the federal and state governments, achieving an acceptable middle ground in the debate over federalism. Baldwin remained on the Court until his death in $1844 .^{61}$

To live in the frontier, away from the civilized center, is to take a risk; it is to flirt with the potential violence and brutality of the unknown, and to imply a rebellion from the norms of the civilized center. To dissent from the established

\footnotetext{
${ }^{58}$ Ex parte Bradstreet, 31 U.S. 774 (1832).

59 Henry Baldwin, A General View of the Origin and Nature of the Constitution AND GOVERNMENT OF THE UNITED STATES (1837).

${ }^{60}$ HUEBNER, supra note 55; JOHNSTON, supra note 30.

${ }^{61}$ TWENTIETH CENTURY BENCH AND BAR, supra note 51, at 810.
} 
order is also the taking of a risk. It is also a flirtation with violence and an implication of rebellion. To live in the frontier is to dissent, which is perhaps an indication of why themes of dissent, risking and occasional violence are so prevalent in the tales of the early bar of Pittsburgh. Henry Baldwin's ascent to the Supreme Court and his role in institutionalizing dissent on the Court may be seen as a frontier influence on American jurisprudence, coming by way of the habits of the Pittsburgh bar; but by that national institutionalization, it also represents a step in the maturation of Pittsburgh's frontier democratic discourse.

The end of the early bar of Pittsburgh coincides with the Civil War, both chronologically and in terms of the spirit of dissent. While the Civil War was a violent episode in our nation's history, it is arguable that the significant role of Pittsburgh's lawyers in the Union Army during the Civil War-approximately 115 Allegheny County lawyers were in active service, ${ }^{62}$ including many middle-aged lawyers who left behind families and well-established, lucrative practices-does not serve as additional evidence of their predilection for violent dissent; rather, it represented a bodily pledge of loyalty to the establishment of order. In an odd way, the lawyers who gave their lives and limbs to the cause of preserving the union were doing so in a most sober expression of the aspirations of Hugh Henry Brackenridge - an affirmation, not a rebellion. The end of the early bar was the end of the Pittsburgh "no"; but, as we shall see in the companion to this piece, ${ }^{63}$ with the meteoric rise of Pittsburgh's economy during the last half of the 19th century, Pittsburgh's lawyers would build upon other quirks of the frontier psyche in embracing a Pittsburgh "yes."

62 See Historical Society of Western Pennsylvania, Celebration of One Hundredth ANNIVERSARY OF THE INCORPORATION OF THE CITY OF PITTSBURGH (1916).

${ }^{63}$ Ron Schuler, Capital, Labor and Lawyers: The Changing Roles and Rising Influence of the Pittsburgh Bar During the Gilded Age, 73 U. PITT. L. REV. 679 (2012). 